\title{
Further clarity on cooperation and morality
}

\author{
David S Oderberg
}

Correspondence to Professor David S Oderberg, Department of Philosophy, University of Reading, Reading RG6 6AA, UK; d.s.oderberg@ reading.ac.uk

Received 19 February 2016 Revised 5 August 2016 Accepted 21 August 2016 Published Online First 3 October 2016

\section{SLinked}

- http://dx.doi.org/10.1136/ medethics-2015-103177 - http://dx.doi.org/10.1136/ medethics-2016-103529 - http://dx.doi.org/10.1136/ medethics-2016-103884 - http://dx.doi.org/10.1136/ medethics-2016-103885 - http://dx.doi.org/10.1136/ medethics-2016-103928 - http://dx.doi.org/10.1136/ medethics-2016-104082 CrossMark

\section{ABSTRACT}

I explore the increasingly important issue of cooperation in immoral actions, particularly in connection with healthcare. Conscientious objection, especially as pertains to religious freedom in healthcare, has become a pressing issue in the light of the US Supreme Court judgement in Hobby Lobby. Section 'Moral evaluation using the basic principles of cooperation' outlines a theory of cooperation inspired by Catholic moral theologians such as those cited by the court. The theory has independent plausibility and is at least worthy of serious consideration -in part because it is an instance of double-effect reasoning, which is also independently plausible despite its association with moral theology. Section 'Case study: Burwell v. Hobby Lobby' examines Hobby Lobby in detail. Even if the judgement was correct in that case the reasoning was not, as it involved applying a 'mere sincerity' test to the cooperation question. The mere sincerity test leads to absurd consequences, whereas a reasonableness test applied using the theory of cooperation defended here would avoid absurdity. Section 'A question of remoteness: "accommodations" and opt-outs' explores the post-Hobby Lobby problem further, examining opt-outs and accommodations: the Little Sisters of the Poor case shows how opt-outs are misunderstood on a mere sincerity test, which the court rightly rejected. Section 'Application to the medical field: Doogan and Wood' discusses the UK case of Doogan and Wood, concerning participation in abortion. Again, a judicially recognised ethic of cooperation, if it were part of the fabric of legal reasoning in such cases, would have enabled the conscientious objectors in this and similar situations to have their freedom of conscience and religion respected in a way that it currently is not.

\section{INTRODUCTION}

Healthcare is perhaps the most prominent area where the issue of conscientious objection arises. It usually takes the form of an objector who regards involvement in a certain practice, such as abortion or euthanasia, as violating their sincere religious beliefs. The cases nearly always involve Christians, but in theory could encompass anyone with a conscientious objection, religious or not. Some jurisdictions employ 'conscience clauses' that exempt doctors and other practitioners from participating in the objectionable activity (usually abortion) without further justification required. ${ }^{12}$ The theoretical problem is, however, wider than abortion and even euthanasia, and is not solved by this or that particular conscience clause.

The problem, I submit, is not whether secular, pluralistic societies should protect freedom of religion (and conscience) in healthcare and other activities where conscience might be an issue, but how. Piecemeal conscience clauses are ad hoc, potentially conflicting and insufficient. Rather, both government and the law need to provide a general, overarching protection for freedom of religion. In particular, it is inadequate protection to exempt a healthcare practitioner from participating in an objectionable act (to use the terminology of s. 4 of the Abortion Act 1967). 'Participation' suggests direct involvement in the performance of the objectionable act, which is how the UK Supreme Court interpreted it in the recent case of Doogan and Wood, ${ }^{3}$ about which more later. Involvement in an act, however, can go further than participation. Involvement can be constituted by cooperation with an act. A cooperator does not perform what we might call the 'principal act', the one the cooperator objects to. Rather, they assist in its performance, whether closely and directly or in a more remote and indirect fashion. It is not a mere matter of 'aiding and abetting' as in the criminal law, where the jurisprudence is rather haphazard and unsystematic, and tends to concern itself with relatively close and direct forms of complicity. More importantly, the criminal law of complicity is narrowly focused on intentional assistance, whereas the kinds of cooperation of relevance to the present discussion are usually unintentional. Conscientious objectors are not concerned about intentional assistance-the direction of their will, as it were, to the commission of the principal act. On the contrary, they object to situations in which they are compelled by law to engage in behaviour that objectively assists a principal agent but they do not intend for the principal to do that which the cooperator finds objectionable.

There is at present no civil jurisprudence on cooperation in wrongdoing, yet there is an urgent need, in my view, for a relatively worked-out set of principles that courts can apply, with their customary sensitivity to detail, in particular cases. Perhaps it should be backed up by an overarching legislative scheme, such as that embodied in the famous US Religious Freedom Restoration Act (RFRA) 1993. ${ }^{4}$ Unlike Article 9 of the European Convention on Human Rights, for example, the RFRA provides a specific test of whether freedom of religion is being violated. A test would give legislative backing to the sort of case law that would take time to build up and might specify that compelled illicit cooperation was one way of failing the test.

Be that as it may, the courts still need to take more notice than they have of ways in which a religious objector might consider cooperation to violate their sincerely held beliefs, especially in health-related areas. The US Supreme Court recently did so in the landmark Hobby Lobby judgement. ${ }^{5}$ In what one commentator has called "one of the most philosophically sophisticated footnotes I've seen in a Supreme Court decision 
recently", 6 the court saw the case as hinging on "a difficult and important question of religion and moral philosophy, namely, the circumstances under which it is wrong for a person to perform an act that is innocent in itself but that has the effect of enabling or facilitating the commission of an immoral act by another" (p. 36, n. 34). As well as citing previous work of my own, ${ }^{7}$ Alito J, writing for the majority, cited two mid-twentieth-century Catholic moral theologians. ${ }^{8} 9$ Many other works with the same approach could have been cited, perhaps the best of them being McHugh and Callan. ${ }^{10}$ One might wonder what place Catholic moral theology has in a secular court judgement but the fact is that, among the various religions, Catholic theologians have written at length on the ethics of cooperation, developing a systematic framework for the evaluation of particular acts.

As we will see, the kind of system theologians have worked out is relatively commonsensical rather than arcanely theological in nature. A point to note is that it would be misguided to suppose that the ethics of cooperation in wrongdoing as I set it out here is essentially connected to some particular conception of moral wrongdoing or even to wrongdoing at all. A person may cooperate with another's perfectly permissible or even morally obligatory action, from something as mundane as my cooperating with your cleaning your car to cooperation with an admirable act of helping someone in dire need. All the same structural features of cooperation apply-whether it is formal or material, proximate or remote, dispensable or indispensable, as I will explain later. But there is rarely a question of whether cooperation in 'rightdoing', as it were, is permissible. (Thanks to Steven Skultety for emphasising this point to me.)

One should also not be troubled by the Supreme Court's drawing on religious sources as inspiration for its judgement. I would go further and claim, as I will argue below, that it is essential for the ethics of cooperation not to be seen as necessarily religious in nature in order for it to have proper application to disputed cases, whether or not brought by religious litigants. Moreover, the Supreme Court itself, on my reading of the case, violated this requirement by producing a ruling that has led to a jurisprudential quagmire from which the US courts have not yet begun to extricate themselves. I now turn to an outline of the way principles of cooperation can be used for the moral evaluation of particular acts. Seeing the principles in action, as it were, should lend support to their independent plausibility, whatever their origin.

\section{MORAL EVALUATION USING THE BASIC PRINCIPLES OF COOPERATION}

We start with what I will call 'methodological neutralism', as do the US courts in religious freedom cases. The evaluation is of an action that involves cooperation with a primary or principal act the objector sincerely believes to be wrong. That belief (call it the primary belief), we assume, derives from or is embodied in religious teaching, whatever other grounds might be invoked, and the objector adheres to that teaching. The US courts do not second-guess the objector, in the sense of looking behind the sincere belief to whether it is reasonable or not. ${ }^{11}$ So when I speak of wrongdoing, I mean the primary act that the objector sincerely believes, on religious (or broadly conscientious) grounds, to be wrong.

We should accept, and I will not discuss it further here, that formal cooperation in wrongdoing is itself wrong. This means that the cooperator assists the principal agent precisely out of an intent that the wrongful principal act be performed. If rape is wrong - and we all rightly think it is-then it is wrong to assist in a rape (without performing it oneself) with the intention that the victim be raped. If abortion or euthanasia are wrong, the same applies. The formal cooperator approves of the principal act and so shares in the guilt of the primary agent. And he can do so even if he does not see the principal act as wrong. A person might think it just fine to rape someone as an act of revenge, say, and so approve the act, without thinking the act wrongful. In other words, approval of the wrongful act does not entail thinking of it as wrong, and in fact usually occurs in conjunction with the belief that it is somehow justified.

My concern here, however, is with cases of material cooperation: these are the sorts of case that have rightly generated so much litigation and judicial angst in the USA. Material cooperation does not proceed from a wrongful intent. The material cooperator is a reluctant or unwilling assistant who might know what the principal agent intends but who cooperates out of fear, pressure, inducement and more generally a desire to avoid some loss or gain some benefit to herself or a third party.

The evaluation of material cooperation, if it is not to involve a random assortment of thoughts and hunches, needs systematisation. Here, I submit, appeal to double-effect reasoning (more solemnly, the principle of double effect (PDE)) can give us just the system we need. Indeed, the explanatory power of double-effect reasoning-its usefulness in offering a reasonable system for evaluating material cooperation-provides indirect support for the reasoning itself. The point I want to emphasise is that whatever its origin in moral theology, the ethics of cooperation defended here has independent appeal both in terms of the kinds of principle it invokes and its structural similarity to double-effect cases. Needless to say, the PDE has its many critics so I need to reiterate why, at least in outline, we should think that the ethics of cooperation has merit because of its being an application of the PDE.

The basic idea is that the fundamental principle of practical reasoning is to do good and avoid doing bad, but unless this principle requires more than can be expected of a finite human agent it has to be qualified. Since so much of what we do has bad effects whether we intend them or not, and no sane moral system can entail that we are acting wrongly most of the time (in the ordinary course of events), we have to be permitted to cause bad things to happen-although within strict requirements. That, in essence, is what the PDE is all about. More specifically, the PDE codifies the basic idea into a set of principles for evaluating relevant cases. In brief, the following must hold for an act causing both good and bad effects to be permissible: (1) it must itself be morally permissible; (2) the bad effect must only be foreseen, not intended; (3) the bad effect must not be used as a means to the good effect; and (4) there must be a proportionate reason, in the nature or circumstances of the good effect, sufficient to justify allowing the bad effect to occur. There is no space here to justify the PDE in general (see ref. 12); rather, I want to show its plausibility when applied specifically to cases of cooperation.

We cannot participate directly in the commission of an immoral act. Translated into the terminology of cooperation, we cannot-or so I contend-cooperate immediately in the primary act even if the cooperation is merely material. Hence, joint performance of the whole act, or performance of a part of it, should be ruled out because of violating clause (1) of the PDE even if the cooperator in no way approves of the principal act and so is not a formal cooperator. Example: Joe acts wrongly if he participates in a gang rape even if he does so only out of fear or to ingratiate himself with the gang. In other words, if the behaviour looks like whole or partial execution of 
the primary act, and the primary act is wrong, the immediate cooperator acts wrongly.

The wrongness of immediate cooperation, even where the cooperator does not share the primary agent's intent, seems intuitive. What about mediate cooperation, where there is no joint or part performance? Again, on the theory I am defending intuitively plausible classifications and distinctions can be made. Mediate cooperation should be thought of as the supply of means or conditions for the primary act to take place. It is also, to use the double-effect terminology, 'morally neutral' or 'morally indifferent'. A morally neutral act is not one that has no moral character to it; rather, it is one that is morally permissible in the ordinary course of affairs, but that takes on a questionable flavour due to its being used to serve an immoral objective. Here we are concerned with act-types rather than tokens. Rape, or torture of the innocent, are types of act that are not morally neutral. Handing over keys, holding a ladder, passing on information, driving a car-these are morally neutral act-types that do not of themselves merit condemnation. According to the PDE, morally neutral acts that produce both good and evil effects may licitly be performed only under certain conditions.

One of the conditions, apart from moral neutrality, is that the benefit (or avoidance of loss) to the material cooperator should not be caused by the primary act but should result directly from the cooperative act. This is clause (3) of the PDE as applied to cooperation. The idea behind it is that if the benefit proceeds from the primary act, and the primary act is immoral, the cooperator is using an immoral act as the means to a good end, which-on the plausible assumption that immoral acts cannot be used as means to good ends-makes the cooperation impermissible even if the cooperative act is itself morally neutral. Example: Tom hands Vincent money for the purchase of a boat to be used in people-trafficking. The incentive is that Vincent will pay Tom double from the proceeds of the trafficked victims. Tom thinks Vincent's act is wrong but he is still prepared to use it as a means to his benefit. This sort of cooperation is, I claim, impermissible but it is also not typical of material cooperation since, usually, the incentive is independent of the results of the primary act.

By far the most important condition in cases of material cooperation, and the most difficult to apply, is that of proportionality. Clause (4) of the PDE has it that there must be some sort of equivalence between the good the agent seeks to achieve and the evil they unintentionally bring about. The condition is not hard to appreciate: every time a person drives a car they contribute, in a tiny way, to air pollution, but we justify most trips by the good they achieve or the loss they avoid. Every time the dentist causes unavoidable pain, she justifies it on the ground of the good to be achieved. A system of moral rules that did not make room for such justifications and the behaviour to which they apply would be absurdly onerous; most human activity would grind to a halt. We rightly expect, however, some kind of proportion between the good and evil effects. There is no room here for a detailed exploration of proportionality in general: what matters for our purposes is that such proportionality be necessary and that it be applied in a particular way to cooperation cases.

In standard double-effect cases (where cooperation is not an issue), we would expect merely an assessment of the relative goods and evils involved, for example: causing serious physical harm as against a minor benefit, endangering the public good as against a private benefit and harming life as against preserving property. One need not believe in the PDE as such to see how plausibly to 'weigh goods and evils' in double-effect-type cases. It is important to note that proportionality judgements are also informed by a suite of considerations and sub-principles, all of which are in accord with intuitive moral thinking. For instance, the agent is expected to minimise the risk of the bad effect where feasible as well as its severity. An agent under a prior duty to act in a certain situation (such as an on-duty police officer or a soldier) needs a more serious reason for permitting a given evil than someone not under a prior duty. Again, the greater the probability of the evil effect, the more serious the reason the agent needs for permitting it.

It will be objected that proportionality judgements can take a variety of forms. The kind of reasoning involved is typically non-consequentialist, but one could perhaps conceive of some sort of consequentialist calculus as the criterion of proportionality. Hence, clause (4) should not be rejected out of hand because of its common non-consequentialist character, though a consequentialist would almost certainly reject the PDE as a whole because the overall schema is essentially opposed to her method of moral evaluation. One might compare effects solely by reference to the virtues of the cooperator through which the effects are brought about. One might even deny that any kind of proportionality judgement is possible. (Thanks to an anonymous referee for pressing this point.) So why should the way I suggest proportionality be assessed have any superior claim? In reply, I do not pretend that other approaches stand no chance of relative success. Nor do I have space to give a detailed defence of the method I prefer, the one classically associated with the PDE. What I do suggest is that there are broad criteria of assessment that ought to commend themselves independently of commitment to any particular normative theory. Further, the classical way of assessing proportionality in double-effect cases fits in well with the more specific cooperation cases that are my concern. There may be other, equally plausible ways of assessing proportionality that sit well with what we should say more broadly about the ethics of cooperation. I leave it others to pursue such projects, and there is no space here directly to confront total scepticism about proportionality judgements.

When it comes to cooperation cases, there are special considerations that must be factored into the evaluation process, revolving primarily around the 'proximity' question. The overarching idea is that when we assess whether a material cooperator's act is permissible given the wrongness of the primary act in terms of the benefit or avoidance of loss for which reason the cooperator assists the principal agent, we have to ask: how implicated is the cooperator in the principal act? In other words, how tightly connected is her act to that of the principal? By these terms of art, we seek to capture the idea that sometimes a cooperator, no matter how unwilling, cannot justify their assistance in the circumstances because they partake too much of the guilt of the principal by the closeness of their involvement. Another way of putting it is that the cooperation has too much of an executive character to be justifiable in the circumstances. Here, concepts of proximity and dispensability are central. Proximity concerns where in the causal chain leading to the principal act the cooperator stands. Dispensability is about how practically necessary their assistance is in the circumstances. In general, we should say that the more proximate and indispensable the cooperation, the graver the reason the agent needs for cooperating.

Proximity is not necessarily a spatio-temporal matter. Typically, the more proximate the cooperation, the closer in space and time it will be to the primary act. But it might be proximate even though spatio-temporally distant, given the 
small number of significant causal steps from cooperative to primary act. Example: Victor sets up a distant roadblock so that William, a terrorist, can plant an explosive device. Assume conditions are otherwise calm and uneventful. All that William needs for the explosion to succeed is that the roadblock be effective for a certain period and that everything else proceed as normal. Victor might do his part weeks in advance, with William having to put the final pieces in place only minutes before the explosion. Victor's cooperation is proximate to a high degree even if separated by a long distance and time period from completion of the principal act.

Indispensability contributes to executive character because if a cooperator does something that is causally necessary (practically speaking) for the principal act to take place, we should say that the cooperator is significantly more implicated than if the principal agent can achieve their objective relatively easily without the assistance. Compare supplying a password to someone who wants to commit a fraud when the cooperator is the only source of information, with the case where the fraudster can easily obtain the password in another way. Greater reason is needed for cooperation in the former than in the latter case.

Proximity and indispensability have to be combined with assessment of the seriousness of the primary act and of the benefit to be gained/loss to be avoided by the cooperator. Any reduction in either proximity or indispensability lowers the overall reason threshold. There is no space to detail all the various permutations that obtain, but note that ane extreme we have cooperation that is highly proximate and absolutely indispensable to a seriously immoral act, where the benefit gained/loss avoided by the cooperator is slight. Example: Michael risks a loss of face with his fellow gang members if he does not provide an essential weapon for a murder. I assume here the loss of face is mild; it is a key principle that what counts as a loss or benefit varies with circumstances, and in some contexts the same loss of face could be serious, leading to ostracism. At the other extreme, we have cooperation that is very remote and quite dispensable to a minor wrong, where the benefit/loss is great. Example: Jenny, a council employee, is threatened with dismissal if she does not quickly find someone to repair a shredder so her employer can dispose of documents incriminating him in some petty bureaucratic offence. Assume Jenny is one of several people who could have been asked to assist and that the inconvenience to the employer would have been mild had Jenny not complied.

Between these two extremes lie a spectrum of cases: the closer and more indispensable the cooperation and the graver the primary wrong, the greater the benefit/loss to the cooperator must be before cooperation is permissible. If the necessity of comparative assessments means there is no clear cut-off line between permissible and impermissible cooperation, as it surely does, we must simply say-as in all difficult moral cases-that an agent, when in doubt, should play safe. Objectively speaking, if both cooperation and abstention are equally justifiable, the agent may cooperate or abstain. A debatable qualification is that the principle of safety might plausibly come into play even here, inasmuch as the risk of cooperating in a serious wrong means an agent should abstain even if they are presented with equally strong justifications for cooperating and refusing to cooperate.

The reader might baulk at the extent to which notions of degree or comparison permeate the discussion thus far, but we must recall Aristotle's dictum that we should not expect more precision than the subject matter allows. There is, in particular, no such thing as proximate cooperation tout court, that is, with no implied comparison to other actual or possible cooperation in a given situation. When we say, for example, that handing over an instrument to a surgeon is proximate cooperation in the surgery, we mean relative to such an act as anaesthetising the patient. But this does not make administering anaesthetic remote pure and simple since it is proximate relative to handing the patient a preoperation meal. Cooperative acts are more or less proximate in the circumstances relative to what else is being done (or even might have been done). This kind of relative aspect to cooperation does not make evaluation impossible; it is, rather, a prerequisite for making evaluation, for otherwise we would have to draw artificial and implausibly absolute lines between kinds of act.

There is, needless to say, much more detail that can be spelled out, but we have enough material for our purpose of examining a pressing issue-one whose importance is only likely to increase over time-in which the ethics of cooperation plays a central role.

\section{CASE STUDY: BURWELL V. HOBBY LOBBY}

In June 2014, the US Supreme Court handed down a landmark decision in Burwell v. Hobby Lobby, ${ }^{5}$ in which the court held that, as applied to "closely held for-profit corporations", the "contraceptive mandate" implemented under the Affordable Care Act 2010 (Obamacare) violated the Religious Freedom Restoration Act 1993. The mandate requires employers to provide, via their employee health insurance plans, contraceptive coverage with no cost sharing for employees who request it. The plaintiffs challenged the mandate on the ground that compliance violated their sincerely held ethical and religious belief in the immorality of abortifacient forms of contraception. This, they argued, violated the RFRA, which requires the government not to burden substantially a person's religious freedom, even with a law of "general applicability", unless it can show that the law is the "least restrictive means" of furthering a "compelling government interest". ${ }^{13}$ The judgement is important in various respects but for my purposes, and key to the plaintiffs' success in the case, is the issue of cooperation.

The court accepted that the plaintiffs would be cooperators and that the cooperation constituted a substantial burden on their exercise of religion, contravening the RFRA. Nevertheless, even if we accept the correctness of the judgement that illicit cooperation was involved, thus implying failure of the substantial burden test, I contend that the judgement was seriously flawed in a crucial respect. The court took the plaintiffs' belief about the immorality of their cooperation as itself an ethical or religious belief whose sincerity was sufficient for bringing it within the ambit of the RFRA. This is why the court took notice of the cooperation issue and marked it as "difficult and important" but without treating it as a question of law itself, only as one of "religion and moral philosophy".

Consider the court's analysis in the key pages of the judgement devoted to the cooperation question (pp. 35-8). The defendant, the Department of Health and Human Services (HHS), argued (with the principal dissent, Ginsburg J, agreeing) that the connection between what the plaintiffs were required to do under the mandate (provide coverage for abortifacient contraception) and the act to which they objected (destruction of embryos) was "simply too attenuated". Providing the coverage, argued HHS, "would not itself result in the destruction of an embryo"; such destruction required a health plan beneficiary to choose to "take advantage of the coverage and to use" the contraceptive methods objected to (p. 35). For the court, this argument "dodge[d] the question" posed by the RFRA, which was whether the mandate imposed a substantial burden on the 
plaintiffs in the conduct of their businesses "in accordance with their religious beliefs" (emphasis in the original). Instead, the court added, HHS substituted "a very different question that the federal courts have no business addressing (whether the religious belief asserted in a RFRA case is reasonable)". For the court, the question was simply whether the plaintiffs believed that the connection between providing the coverage and the destruction of an embryo was "sufficient to make it immoral for them to provide the coverage" (p. 36). HHS was wrongly "[a] rrogating the authority to provide a binding national answer to this religious and philosophical question," thereby "in effect ... tell[ing] the plaintiffs that their beliefs are flawed" (pp. 36-7). The court emphasised in the strongest terms its repeated refusal to "presume to determine ... the plausibility of a religious claim" (p. 37, here citing the words of the court in ref. 14), and referred to a similar case involving a pacifist employee in which the court held that "it is not for us to say that line he drew was an unreasonable one" (p. 37, citing ref. 15). In that case, the line the plaintiff drew was between manufacturing steel used to make weapons, which he considered consistent with his ethical and religious beliefs, and making the weapons themselveswhich he did not. As far as the contraceptive mandate was concerned, the court similarly held that the plaintiffs "sincerely believe" that providing the coverage "lies on the forbidden side of the line, and it is not for us to say that their religious beliefs are mistaken or insubstantial" (p. 37). The only question for the court was to determine "whether the line drawn reflects an 'honest conviction' ... and there is no dispute that it does" (p. 38, citing for the term 'honest conviction' the judgement in ref. 15, p. 716$)$.

It is clear, then, that the court in Hobby Lobby treated the very belief that the cooperation was immoral and contrary to the plaintiffs' religious convictions as itself a religious conviction that was not subject to the test of reasonableness. This, I submit, was a mistake-one that will lead, and is already beginning to lead, to further problems. The mistake may not be one of law, given previous judicial decisions, but it is nonetheless philosophical and conceptual, applying both to the current and to previous cases that have applied what we might call the 'mere sincerity' test for cooperation. The mistake involves confusing the primary ethical and religious beliefs motivating the initial objection with what we can think of as the subsidiary beliefs determining both what it means in practice to hold the primary beliefs and what counts as acting contrary to them. The subsidiary beliefs are not, and should not be, wholly above reasonable evaluation even for a methodological neutralist.

There are several categories of primary belief about which a methodological neutralist might consider remaining neutral. In Hobby Lobby, which provides a template for how to think about such cases, we could list the following, but in descending order of definiteness:

i. Contraception (or at least abortifacient contraception) is immoral (and/or contrary to religious belief).

ii. A law mandating contraceptive coverage is immoral.

iii. Some kinds of cooperation in immorality are themselves immoral.

iv. There are moral (religious) principles governing which kinds of cooperation in immorality are themselves immoral.

v. The principles referred to in (iv) are as follows ... (Neither the plaintiffs nor the court set out these principles, but let us assume the kind of theory I defend here.)

vi. Providing contraceptive coverage to an employee is a case of violating the principles set out in (v).
We can see why a neutralist might begin to bridle as she goes down the list, especially with regard to (iv) and (v) but most of all with regard to (vi). It is one thing, she might worry, to be neutral about what an objector considers immoral or contrary to religion, but another to be neutral about what an objector considers to be the principles governing whether the objector counts as acting immorally. It is even more questionable whether one can remain neutral about what an objector considers to be the particular act (or kind of act) whose performance counts as immoral by application of the relevant principles. How can a belief as to whether an act counts as immoral be itself a moral (or religious) belief? Yet it is not uncommon for moral and religious principles to carry their own internal criteria of application, at least when it comes to bodies of belief that are fairly well worked out (and often collected in theological and ethical treatises written by adherents to those beliefs). On the other hand, merely appearing in a treatise written by adherents, or being part of the corpus of their internal jurisprudence, does not ipso facto make the content part of the primary belief system of the adherents. I submit that a theory of cooperation of the kind I am defending, which appeals to concepts such as proximity and indispensability, and instantiating broader doubleeffect reasoning, is eminently detachable from its theological sources and of wholly general applicability. Moreover, the use of the theory to assess whether a particular principal act is permissible or impermissible, even if the permissibility of that act is part of the teaching of some religious code, is not itself a religious matter.

So a neutralist who baulked at applying the mere sincerity test to (iv), (v) and (vi) would have good grounds for doing soespecially in the case of (vi). The court in Hobby Lobby, however, clearly counted these as part of the primary body of belief of the plaintiffs, to which sincerity of adherence was sufficient for their applicability. Even if, let us suppose, (iv) and (v) were rightly counted as part of the plaintiffs' primary body of belief, it is extremely difficult to see how (vi) could be since (vi) concerns the mere application of given principles. How can their mere application be itself a purely religious or moral matter? To be sure, 'mere' does not mean 'easy', but even if applying the principles of cooperation is hard and requires delicate judgement, that does not make it a religious or moral matter-in the sense of belonging to one's primary code of beliefs. Application might require appeal to primary beliefs, of course, which is part of why we need to take matters on a case-by-case basis. But there is nothing in the principles of cooperation set out earlier that gives them this flavour. Application requires good sense, sound logic, discernment and a general commitment to taking morality seriously without asking of agents more than they can reasonably be expected to do.

The court in Hobby Lobby, then, applied the mere sincerity test to categories of belief to which it ought not have been applied. Interestingly, however, in this particular case the result is the same as would have been reached, I contend, had the plaintiffs' beliefs about cooperation been subject to a reasonableness test by application of the principles set out earlier. (1) On the assumption that (abortifacient) contraception is wrong, the plaintiffs were being asked to cooperate in wrongdoing. Specifically, the plaintiffs were required by law to cooperate with the employee using the contraception paid for by the plaintiffs via insurance, with the doctor prescribing it, and with the insurance company providing the coverage. (2) The plaintiffs were unwilling to cooperate; hence, they were potential material cooperators. (3) Their cooperation would have been mediate since they were supplying the means for contraception to be 
used, namely paying the insurance company. (4) The cooperation would have been dispensable because there were other ways the employees could relatively easily gain access to contraception. As the court in Hobby Lobby stated, the government itself could have easily assumed the cost of the coverage, and there were alternative mechanisms as well (pp. 40-5). (5) The cooperation would have been relatively proximate. The plaintiffs were being asked to subsidise, although indirectly, behaviour they considered wrong. It was not a matter of, for example, pooling money via taxation into a general fund from which resources could be obtained to facilitate certain general kinds of behaviour, but rather of contracting with another party to finance specific, identifiable behaviour. Overall, then, we have a case of mediate, material, dispensable and proximate cooperation. (I leave aside another important factor that might well violate the very first clause of the PDE-that the action itself must be morally permissible. Arguably, though there is no space to defend the claim here, the very purchasing of health coverage with contraception as an essential element would make the cooperative act impermissible from the outset-again, on the assumption abortifacient contraception is wrong. If so, the rest of the analysis would be redundant.)

Dispensability rubs against proximity in this case and weighs significantly against the plaintiffs, but once the proportionality test is applied we can see that on balance the plaintiffs' cooperation would have been unlawful on the principles set out here. The plaintiffs were subject to significant financial penalties for not cooperating, penalties that over time may well have put them out of business. Nevertheless, what they were objecting to was behaviour they considered gravely immoral, undermining the primary code of ethical and religious beliefs held by the executives of the plaintiff corporations-the destruction of human life through the use of certain methods of contraception. The clear lack of proportion between the wrong in which the plaintiffs were required to cooperate and the loss they could avoid by cooperating, combined with the proximity of the plaintiffs to the primary act, outweigh the dispensability of the cooperation itself.

This, I contend, is the sort of test the Supreme Court should have applied to the case, rather than the mistaken mere sincerity test applied across the board. The result may well have been the same, but the former approach would have obviated the serious problems generated by the latter.

\section{A QUESTION OF REMOTENESS: 'ACCOMMODATIONS' AND OPT-OUTS}

What problems? The general concern is that if the mere sincerity test is applied to complainants' beliefs about (1) whether they are cooperating at all and (2) whether, if so, their cooperation is morally impermissible, absurd results will follow. Examples: Patricia, a pacifist, refuses to work on a farm supplying food to the military (whether combat or not); she refuses to work in an office typing condolence letters to the families of deceased soldiers; she refuses to assist in the burial of deceased soldiers. A person might get the facts wrong and think they are cooperating when they are not, say by assuming they are making swords when they are only making ploughshares. Yet this is hardly the sort of case that raises concerns. The problem lies with situations where no one is mistaken about the facts but where mere sincerity of belief overrides the reasonable application of ethical principles to the known facts. A pacifist might object to all wars, but it would be unreasonable for her to think that every war was as gravely wrong as every other-that a war to recover long-settled territory invaded by a neighbouring country was as bad as a war of enslavement or genocide against an innocent neighbouring population. Remoteness might be outweighed by the gravity of the wrong in the latter case, but in the former we should say that remote material cooperation is justified by a normally serious reason, such as loss of wages or public opprobrium, let alone threat of dismissal or worse. Now whether or not supplying food to non-combat personnel counts as remote, typing condolence letters or assisting in burials is surely remote, doing no more than contributing in a small way to the maintenance of morale. Yet the mere sincerity test makes it impossible to apply reasonable distinctions between these kinds of case.

It seems, indeed, that the terrain of future controversy is being shaped significantly by questions concerning 'opt-outs' and the refusal of objectors to be in the least involved in any causal chain that terminates in what they consider to be an immoral act. In Hobby Lobby, the plaintiffs sought to be included in the exemption from the mandate to provide contraceptive coverage. They did not object to having to do anything in particular in order to obtain the exemption. In other recent cases, however, plaintiffs have objected to the very idea of being given an opt-out from the mandate, that is, to having to perform certain acts that would enable them to benefit from the exemption.

One of the most important recent cases is Little Sisters of the Poor v. Burwell ${ }^{16}$ (and see too Priests for Life, ${ }^{17}$ in which a religious non-profit organisation also objected to the contraceptive mandate as substantially burdensome to freedom of religion under the RFRA). The difference from Hobby Lobby is crucial: whereas in Hobby Lobby the Supreme Court held that the objectors (owners of closely held, for-profit corporations) were entitled to the same accommodation granted to religious nonprofits, allowing them to opt out of providing the relevant insurance coverage, the objectors in Little Sisters of the Poor and then in Zubik v. Burwell ${ }^{18}$ objected to the very accommodation itself. For the accommodation to operate, the objector must certify in writing that it objects to implementing the mandate, either by a form sent to its insurance provider or third-party administrator, or by a letter to the government. In other words, the objector must explicitly opt out of proceedings that implement the mandate. Once they do so, it is up to the insurance company (or third-party administrator) to arrange the necessary coverage.

The plaintiffs objected that the accommodation still made them cooperators in wrongdoing by turning them into 'facilitators' of the objectionable coverage through the opt-out mechanism. By self-certifying as objectors, the plaintiffs claimed they were "triggering" the coverage, maintaining health plans that served as "conduits for the delivery of the mandated coverage" and effectively signing "permission slips" for the provision of the coverage (Little Sisters, p. 59). The Tenth Circuit Court of Appeals rejected these claims: in its opinion, the accommodation did not have such a character. Rather, it was designed specifically to distance the employer from the objectionable coverage. The coverage was not triggered by the opt-out but by the law as implemented by the insurance company. The selfcertification notice was kept separate from any documentation enabling the employee to obtain contraception under the regulations. The plaintiffs were not required "to provide, pay for, or facilitate contraceptive coverage" (p. 42). The opt-out mechanism imposed only "de minimis acts of administrative compliance that are not substantial for RFRA purposes" (p. 50). The plaintiffs remained free to voice their objections to contraception. In short, the accommodation was an opt-out and no more: if the 
plaintiffs objected to providing the coverage, they had to notify the relevant bodies; and those bodies had to step in to provide what the plaintiffs would not.

At least as far as the accommodation goes, the court's reasoning aligns with the kind of philosophical analysis I have provided. The very purpose of an opt-out mechanism is to provide a means for an objector not to be a cooperator in an immoral act. It seems absurd on its face, then, should reasonable interpretation of the mechanism entail that it too involves illicit cooperation. To take an example (ref. 17 p. 24, citing ref. 19 pp. 17-18), if a pacifist is allowed to opt out of military service by self-certifying as a conscientious objector, it would be bizarre for him to argue that the very self-certification was illicit cooperation in war because this would 'trigger' the drafting of someone else. Practically speaking, it is hard to see what other path to exemption could be implemented. Even were the government to keep a prior register of all pacifists, exempting them whenever the country went to war without requiring further self-identification, the objector would have to argue that selfcertification was illicit cooperation even if it involved the keeping of a general register. Were the objector to claim that a prior register was sufficiently remote cooperation to be acceptable, he would have to be reminded that substantial priority in time is neither necessary nor sufficient for remoteness (see above): a prior register would be as much a mechanism for allowing draft replacement as on-the-spot self-certification. Neither, however, should be seen as mechanisms or triggers at all, in the sense of illicit cooperative acts. Opting out is a form of extrication, not implication, and we saw that for cooperation to be relatively proximate it needs to implicate the cooperator in the guilt of the principal agent. A mere condition for the primary act does not take on the colour of proximate cooperation without its having some sort of executive characterwhereas opting out is the opposite of execution. Moreover, in both the draft case and the contraceptive mandate case, the putative cooperation would be entirely dispensable: the government can prosecute its war, or implement its healthcare mandate, without exempting conscientious objectors or religious bodies. One might even argue more strongly that opting out never has the character of a cooperative act at all, and so does not even fall within the umbrella of the cooperation question. This, I think, would be too strong: opt-out procedures might have mechanisms attached that facilitated the primary act, say by automatically identifying the next person on a list who was liable to cooption in respect of some illicit primary act. In general, however, we can safely say that whatever else we might claim about opt-outs, they rarely implicate participants in a morally unacceptable way.

An objector might respond that my evaluation misses the mark. For suppose (to take an example raised by the plaintiffs in Priests for Life, Petition for Rehearing En Banc, ${ }^{20}$ pp. 9-10) the government required free lunches to be served in all schools on pain of substantial financial penalty, and that this included the serving of ham sandwiches. A Jewish or Muslim school would rightly object to paying for the objectionable lunches and might be offered an opt-out whereby the school's lunch provider was then tasked with paying for and providing the ham sandwiches itself. The school might still object that it was being forced to cooperate illicitly in the provision of objectionable food on its premises even though it was not paying for it. Perhaps none of its employees even served it, assuming an independent caterer maintained a separate outlet in the school for students to obtain the sandwiches if they so wished. The school might complain that by contracting or maintaining some other relevant relationship with the provider it was triggering or facilitating the objected-to behaviour.

This sort of case highlights how, legally speaking, the mere sincerity test enshrined in Hobby Lobby raises more problems than it solves. Conscientious objection in the ham sandwich case would not be absurd: it might well fall within the RFRA's sphere of protection. It would still, however, be ethically confused. What the objector resiles from in the ham sandwich case, as in the contraceptive opt-out case, are the very laws permitting the primary acts in the first place. It is a conceptual mistake to confuse objection to the primary acts themselves with objection to any form of cooperation with their implementation even if the cooperation is so remote as to be itself morally permissible. The mere sincerity test, by allowing in principle any group to withdraw from any cooperation with a law they deem contrary to their moral or religious beliefs, threatens to undermine all kinds of morally legitimate behaviour that is beneficial to others. (Think of the pacifist who refuses to make farm machinery because agriculture supports the war effort, or the objector to contraception who refuses to provide any employee health coverage, and even risks their own bankruptcy, because they see a complete opt-out as a form of illicit cooperation.) Moreover, and perhaps even more importantly, to mask the confusion by painting all forms of cooperation with the colour of primary religious or ethical belief is to miss the ethical point and to risk engaging in morally impermissible behaviour itself, namely abusing the principles of cooperation as a means to crippling the implementation of certain laws, whether or not those laws are themselves subject to reasonable objection. At the very least, such abuse would be scandalous inasmuch as it gave the impression that it was permissible (morally and legally) to manipulate the rules of cooperation in order to obtain a legal objective, however admirable the objective might be.

\section{APPLICATION TO THE MEDICAL FIELD: DOOGAN AND WOOD}

Despite the confusion and uncertainty concerning cooperation in recent American case law, the courts have at least to some extent begun to grapple with the jurisprudence: the judicial notice of cooperation as a serious philosophical issue by the Supreme Court in Hobby Lobby is crucial in this respect. In the UK, however, the courts have not even begun to do the analysis and development that is required. There is, unfortunately in my view, no equivalent of the Religious Freedom Restoration Act with its 'substantial burden' test, hence no statutory stimulus to case law development. The recent UK Supreme Court case of Doogan and Wood ${ }^{3}$ highlights the severe difficulty in which conscientious objectors find themselves. Under s.4(1) of the Abortion Act $1967,{ }^{2}$ no person is under a duty "to participate in any treatment authorised by this Act to which he has a conscientious objection". The petitioners were midwives in Scotland who believed that "any involvement in the process of termination render[ed] them accomplices to and culpable for that grave offence" (p. 7). Since they had a statutory exemption to 'participation', they objected to "delegating, supervising and/ or supporting staff to participate in and provide care to patients throughout the termination process" (p. 9) on the grounds that these were all forms of participation.

The UK Supreme Court, unsurprisingly, gave short shrift to the petitioners' grievance. The term "treatment" in s. 4 could only refer to the actual process of termination itself, but this process amounted to a "whole course of medical treatment" beginning, if required, with the administration of labourinducing drugs and ending with "delivery of the foetus, placenta 
and membrane" (p. 14; in a surgical abortion, by implication, the course of treatment would be even narrower: see also p. 12). In other words, the conscience clause of the Abortion Act was given the narrow interpretation that, on the face of it, the statute demanded. Participation was interpreted as meaning part-performance, and the object of the part-performance was the specific activity that had been illegal before the Act and was made lawful by it-namely, the act of termination itself, at any stage from beginning to end but not including ancillary supervisory, pastoral, administrative or managerial activities.

There is much that can be said about the details of the case, but my key claim is that it is difficult to see how the court could have arrived at any other result-which is precisely the problem. For without a worked-out jurisprudence of cooperation, based on philosophical principles and tempered by the common sense of the common law, with overarching statutory backing, conscientious objectors will find it hard to have any legitimate objection satisfactorily met. Moreover, as contentious as it may be, abortion is but one among many activities within healthcare where objections will undoubtedly arise. What about euthanasia? Transgender surgery? Extreme cosmetic surgery? Apotemnophilia (the persistent desire for the amputation of a healthy limb)? Surely the approach of 'one conscience clause at a time' would be a highly undesirable way to proceed. Returning to the case at hand, the court rejected the petitioners' objection that booking an abortion patient into the ward would be illicit participation (p. 13). By the language of the statute, the court was correct. It was also right implicitly to condemn a 'mere sincerity' test: “The exercise of conscience is an internal matter which each person must work out for herself. It is bound to be subjective" (p. 13). If by 'exercise of conscience' is meant the holding of a sincere belief based on equally sincere reflection and perhaps obedience to one's religious tenets, the court speaks plausibly. But there is more to formation of conscience than mere sincerity, with or without obedience. Conscience needs to be properly formed in accordance with truth, and in this case the existence of a reasonable jurisprudence of cooperation would have enabled the court to discern whether the conscientious objection of the petitioners was reasonable or not, even if their primary religious beliefs were, for neutralist reasons, taken at face value.

The court might have been in a position to hold, for example, that arranging the night shift or managing rest breaks on the ward was remote, dispensable, material cooperation for which a serious reason, such as loss of employment, existed. It would be, so the thought goes, remote because managing shifts and breaks would go on with or without abortions taking place, and such activity has no 'executive character' about it: it does not involve supplying tools or means by which the specific act of abortion takes place. It might be thought dispensable because although the ward could not operate in any respect without a system of shifts and breaks, it might be that no particular midwife needed to manage it since the skills required were fairly generic. (Dispensability concerns both what is done and by whom.) On the other hand, the court might also have held that booking a specific patient in for an abortion was proximate cooperation since this would involve setting the specific process in motion leading to the objectionable primary act. In this respect, booking in a patient provides a tool by which an abortion can take place. It might also be thought indispensable inasmuch as a booking system is a practical causal necessity for any specific procedure to take place, unlike shift management that applies across the board, even if any midwife could operate the booking system. Whatever the court might have said about the indispensability of booking, actual admission of the patient onto the ward would seem to be indispensable cooperation, part of the very means by which the abortion must eventually take place. Proximate, indispensable material cooperation would require a very serious reason to be permitted. Given that what the midwives objected to was the ending of a life, it is hard to see how anything short of a threat to their own lives would have justified cooperating.

My purpose here is not to analyse the facts in this specific case, rather to draw a lesson about what might be achieved by a judicially noticed and developed ethics of cooperation. The courts, especially if they had a statutory framework on which to fall back, could avoid piecemeal recognition of freedom of religion and conscience confined to individual conscience clauses, as compared with the universal right to abortion, say, or transgender surgery, currently recognised by the law. This would put freedom of religion and conscience on a relatively equal footing with these other legal rights, at least as far as cooperation is concerned-which is where the litigation is increasingly directed.

\section{CONCLUSION}

My critique of the mere sincerity test and defence of the moral legitimacy of opt-outs may seem bleak for the conscientious objector to cooperation in wrongdoing: if she concedes that what she is really objecting to is the primary law itself (the one under which the primary acts are sheltered), how is the objector supposed to extricate herself from compliance if not via total noncooperation? In reply, this is not how the objector should think of all laws to which she objects on religious or moral grounds. Laws that she thinks are gravely immoral or contrary to religion are still subject to extrajudicial protest, civil disobedience and all the well-known techniques that have been used, with occasional success, to overturn or replace objectionable laws. Second, pursuit of opt-outs is both legally possible under current jurisprudence-supported by the fundamentally correct result in Hobby Lobby - and morally legitimate if not commendable. Accommodations sought for reasons based on illicit cooperation are potent, precedent-backed mechanisms for keeping an objector's involvement with problematic laws at a minimum.

Third, and perhaps more importantly, the mere sincerity test, by which Hobby Lobby sows much confusion despite the correct result in that case has to be abandoned. Under the current RFRA jurisprudence, plaintiffs have wide scope for mounting successful challenges to cooperating even in matters where it is both morally licit to do so and not contrary to their religious beliefs. Such permissiveness in the law is almost certain to lead to an increasingly restrictive backlash by the courts, which could significantly reduce religious freedom and conscientious objection. If the current mere sincerity test were replaced by a reasonableness test based on objective principles of cooperation along the lines drawn in the present discussion, a more balanced jurisprudence would be likely to follow. A complainant would not have to go to the extreme of arguing that cooperation in a given case was morally wrong and/ or contrary to religion. He would merely have to argue that, while cooperation was morally permissible and/or consistent with religious belief, it was also permissible not to cooperate. The courts would not, then, have a blanket authority to compel cooperation in cases where its illegitimacy on moral and/or religious grounds could not be made out. Rather, courts would have to assess the gravity of the plaintiff's primary objection to the law with which non-cooperation was a permissible course of action. Given methodological neutralism, courts could not look behind the sincerity of that objection in order to judge its reasonableness. (Whether methodological neutralism is itself morally problematic is altogether a different question worth debating.) Still, an 
evaluation of whether the primary act in question did, objectively speaking, conflict with a plaintiff's religious and/or ethical beliefs would have evidential weight in respect of the sincerity with which the objection was held. So, for example, a court might hold, in a Doogan-style case, that given the seriousness with which practising Catholics and conservative Protestants generally regard abortion-as a violation of core tenets of their doctrinal systems-more leniency should be shown in cases of remote cooperation than when the primary act involves, say, extreme cosmetic surgery. In other words, why might a court not be allowed to give weight to the extent to which a plaintiff's conscience is legitimately 'troubled' by involvement, even permissible, with certain primary acts? In particular, if scandal or 'mixed messages' were a risk foreseen by the plaintiff, why should the courts not take that into account? If the courts (and the legislature) are prepared to 'go the extra mile' for other legal rights they consider fundamental, why not for freedom of religion and conscience?

Within this sort of framework even an opt-out might, in a given case, be insufficiently accommodating to give due weight to a plaintiff's fundamental belief system. While the government might have, to use the language of the RFRA, other 'compelling interests' to serve (whether these be reasonable or not), if religious freedom is genuinely to be itself a compelling interest, the courts must allow that non-cooperation might be permissible even in cases where cooperation would not, in itself, be wrong by the objector's own lights or those of reasonable evaluation. All of these considerations, then, argue for the development of a civil jurisprudence of cooperation-one that is broader than the criminal law of complicity and that explicitly imports insights from moral philosophy and theology.

Acknowledgements I am grateful to staff and students at the University of Mississippi for comments on a draft of this paper, as well as two anonymous referees and the Editor-in-Chief for their very helpful insights and suggestions.

Competing interests None declared.

Provenance and peer review Commissioned; externally peer reviewed.

\section{REFERENCES}

1 The Church Amendments to Roe v. Wade (1973): 42 USC $\$ 300 a-7(b)$ etc; http:/l www.consciencelaws.org/law/laws/usa.aspx\#Public\%20Health\%20Service\%20Act\% 201973 (accessed 12 Jul 2016).

2 UK Abortion Act 1967, section 4 http://www.legislation.gov.uk/ukpga/1967/87/ section/4 (accessed 12 Jul 2016)
3 Greater Glasgow Health Board (Appellant) v Doogan and another (Respondents) (Scotland) [2014] UKSC 68. https://www.supremecourt.uk/decided-cases/docs/UKSC_ 2013_0124_Judgment.pdf (page references to the pdf) (accessed 6 Sep 2016).

442 USC 21B. https://www.law.cornell.edu/uscode/text/42/chapter-21B (accessed 2 Aug 2016).

5 Burwell, Secretary of State of Health and Human Services, et al. v. Hobby Lobby Stores, Inc., et al. (2014); slip opinion. https://www.supremecourt.gov/opinions/ 13pdf/13-354 olp1.pdf (accessed 24 Jul 2016). All references to pages in the judgement are to the slip opinion.

6 Jeffrey Rosen, writing in Gans DH, Shapiro I. Religious Liberties for Corporations? Hobby Lobby, the Affordable Care Act, and the Constitution. New York, NY: Palgrave Macmillan, 2014:67.

7 Oderberg DS. The ethics of co-operation in wrongdoing. In: O'Hear A, ed. Modern Moral Philosophy. Cambridge: Cambridge University Press, 2004 (Royal Institute of Philosophy Annual Lecture Series 2002-3):203-27.

8 Higgins T. Man as man: the science and art of ethics. Milwaukee: The Bruce Publishing Co., 1949:353-5.

9 Davis H. Moral and pastoral theology. Vol. 1. London: Sheed and Ward, 1935:341-52.

10 McHugh JA, Callan CJ. Moral theology: a complete course. Vol. 1. New York, NY: Joseph F. Wagner, Inc., 1958:615-41.

11 Thomas V. Review Board of the Indiana Employment Security Division, 450 U.S 707 [1981]; Hernandez v. Commissioner of Internal Revenue, 490 U.S. 680 [1989].

12 Oderberg DS. Moral theory. Oxford: Blackwell, 2000:ch.3.1.

1342 USC 21B $\$ 2000$ bb- 1 .

14 Employment Div. v. Smith, 494 U.S. 872 (1990):887.

15 Thomas v. Review Bd. of Indiana Employment Security Div., 450 U.S 707 (1981):715.

16 Little Sisters of the Poor v. Burwell. https://www.aclu.org/sites/default/files/field_ document/07.14.15_little_sisters_opinion.pdf, US Court of Appeals for the Tenth Circuit (2015), 794 F.3d 1151 (accessed 5 Sep 2016). All references to pages in the judgment are to the slip opinion (header pagination).

17 Priests for Life, et al. v. United States Department of Health and Human Services, et al, http://www.clearinghouse.net/chDocs/public/FA-DC-0001-0010.pdf, U.S. Court of Appeals for the District of Columbia Circuit (2014), 772 F.3d 229 (accessed 5 Sep 2016). (All references to pages in the judgment are to the slip opinion.) The petition for rehearing en banc (in front of the full court) was also denied: http:/l www.americanfreedomlawcenter.org/wp-content/uploads/2013/09/ Order-and-Opinions-re-Denial-of-PFR.pdf (2015) (accessed 5 Sep 2016).

18 Little Sisters of the Poor, Priests for Life and a number of other cases were consolidated into Zubik v. Burwell. https://www.supremecourt.gov/opinions/15pdf/ 14-1418_8758.pdf (2016) (accessed 5 Sep 2016). Given the state of the US Supreme Court at the time Zubik was heard, the Court did not decide these cases on their merits, but vacated all lower court judgments and sent the litigants back to the negotiating table where, at the time of writing, the matter lies.

19 University of Notre Dame v. Sebelius. http://media.ca7.uscourts.gov/cgi-bin/rssExec. pl?Submit=Display\&Path=Y2014/D02-21/C:13-3853:J:Posner:aut:T:fnOp: N:1295328:S:0; see also 743 F.3d at 556 (accessed 5 Sep 2016). All references to pages in the judgment are to the slip opinion.

20 Priests for Life, Appellants/Cross-Appellees' Joint Petition for Rehearing En Banc. http://counsel.cua.edu/res/docs/Joint-en-banc-petition-AS-FILED-2-.pdf (accessed 5 Sep 2016). 